\title{
IMMUNOHISTOCHEMICAL EXPRESSION OF P16 IN CERVICAL AND URINARY BLADDER SQUAMOUS CELL CARCINOMA
}

\author{
By

\section{Esmail T. M. A. El-Bayoumy, Emad El-Din R. Matar, Yasser M. El- Dweek and Ahmad M. Kandil} \\ Pathology Department, Faculty of Medicine, Al-Azhar University \\ Corresponding author: Esmail Talat Mohammed Ahmed Elbayoumy, \\ E-mail: talaatismail72@gmail.com
}

\begin{abstract}
Background: p16 is a tumor suppressor protein important in regulating cell cycle. In bladder cancer, p16 mutations are widespread and tend to be more prevalent in low-grade superficial tumors than in higher-grade invasive tumors.

Objective: To evaluate expression of p16 in 25 cases of cervical squamous cell carcinoma and 25 cases of urinary bladder squamous cell carcinoma.

Patients and methods: This study was carried out in the Histopathology Department of Al-Azhar University Hospitals and from some private laboratories during the period from August 2019 up to January 2020. H \& E stained sections were prepared from paraffin blocks for revision of diagnosis. Immunohistochemical analysis was done on 4 micron sections of formalin-fixed paraffin-embedded tissue using the labeled streptavidinbiotin method after antigen retrieval. Antibodies against P16 were utilized on sections from paraffin blocks. CINtec Histology kit includes a two-step antibody method for detection of human p16 antibody.

Results: Expression of P16 was positive in $92 \%$ of cases of squamous cell carcinoma of the uterine cervix and $60 \%$ of cases squamous cell carcinoma of the urinary bladder. In patients with cervical squamous cell carcinoma, there was statistically significant relation between intensity of P16 staining and tumor grading. In patients with squamous cell carcinoma of the urinary bladder, there was a statistically significant relation between intensity of P16 staining and tumor grading and staging. Moderate/strong staining intensity can predict staging $2 \mathrm{~B}$ among patients with squamous cell carcinoma of the uterine cervix, and negative/weak staining intensity can predict staging $1 \mathrm{~A}, 1 \mathrm{~B}, 2 \mathrm{~A}$ with sensitivity $52.9 \%$ and specificity $37.5 \%$ among patients with squamous cell carcinoma of the urinary bladder.
\end{abstract}

Conclusion: p16 immunohistochemical expression alone should not be used as a marker for differentiation between cervical and urinary squamous cell carcinoma.

Key Words: Cervical cancer, Urinary bladder cancer, P16 (INK4A).

\section{INTRODUCTION}

Cancer of the uterine cervix is the fourth most prevalent cancer affecting women worldwide, after breast, colorectal, and lung cancers. It is considered as the fourth most common cause of death from cancer in women globally. According to the World Health Organization (WHO) newest estimates, In Egypt, 866 women are diagnosed with cervical cancer per year and 373 die from the disease (Ferlay et al., 2013). 
The persistence of an oncogenic human papillomavirus (HPV) infection and a lack of periodic screening are the most relevant risk factors related to cervical cancer. About $90 \%$ of cervical cancer cases are squamous cell carcinoma, $10 \%$ are adenocarcinoma, and a small number are other types. Bladder cancer comes as the ninth most common cancer worldwide and is considerably more prevalent in developed than developing countries (Shafti and Ghalandari, 2018).

In Egypt, where Schistosoma haematobium was endemic, bladder cancer diagnoses were made at younger ages $(<50 \mathrm{y})$ than in developed countries, and $68 \%$ of the cases were identified in histology as squamous cell carcinoma (Zheng et al., 2012). Contrary, in developed countries, over $90 \%$ of the bladder cancer cases are transitional cell carcinoma, while squamous cell carcinoma, adenocarcinomas, and rare types of bladder cancer comprising the remaining $10 \%$ of bladder cancer cases (Fedewa et al., 2013).

Urinary bladder squamous cell carcinoma is a malignant tumor with a pure squamous phenotype derived from bladder urothelim. Squamous cell carcinoma of the bladder is essentially similar to tumours found in other organs. Although some urothelial carcinomas contain a minor component of squamous cells, a diagnosis of squamous cell carcinoma of the bladder should be made only if the tumour is composed solely of a squamous cell component in the absence of a typical component of urothelial carcinoma (Lagwinski et al., 2010).

P16 is a tumor suppressor protein which is a cyclin-dependent kinase inhibitor and is important for regulation of the cell cycle. Cyclin-dependent kinases that phosphorylate $\mathrm{Rb}$ is inhibited by $\mathrm{P} 16$; consequently, p16 can slow down the cell cycle. $\mathrm{Rb}$ phosphorylation status in turn affects expression of p16 in infection with human papilloma virus (HPV), the HPV oncogenes E6 and E7 can inhibit pRB and lead to overexpression of P16. Therefore, overexpression of $\mathrm{P} 16$ is a surrogate marker of HPV infection (Rabban et al., 2010). Deletion and p16 mutation is common in cancer bladder and appear to be more prevalent in low-grade superficial tumors than in higher-grade invasive tumors (Netto and Epstein, 2011).

The aim of this work was to evaluate the expression of p16 in cervical and urinary bladder squamous cell carcinoma.

\section{PATIENTS AND METHODS}

This study was carried out at the Histopathology Department of Al-Azhar University Hospitals and from some private laboratories during the period from August 2019 up to January 2020.

The study included twenty five cases of histologically confirmed squamous cell carcinoma of the uterine cervix and twenty five cases of histologically confirmed squamous cell carcinoma of the urinary bladder.

$H \& E$ stained sections were prepared from paraffin blocks for revision of the diagnosis. Specimen types involved biopsies, transurethral resections, and cystectomy specimens for squamous cell carcinoma of the urinary bladder. In squamous cell carcinoma of the cervix, types of specimen involved cervical biopsies and total hysterectomy specimens. 
For immunohistochemical study, histopathologic slides were reviewed using standard histomorphologic criteria. Immunohistochemical analysis was done on 4 micron sections of formalin-fixed paraffin-embedded tissue using the labeled streptavidin-biotin method after antigen retrieval, as earlier described.

Antibodies against P16 were utilized on sections from paraffin blocks. The CINtec Histology kit includes a two-step antibody method for the detection of the antibody of the human p16. A monoclonal mouse antibody (INK4A) directed against the human p16 protein is the first antibody. A secondary antibody, for visualization purposes, involves a polyclonal goat anti-mouse antibody conjugated with horseradish peroxidase.

These steps were performed and only validated in the included epitope retrieval solution on formalin-fixed, paraffinembedded tissue after heat-induced epitope retrieval at $95-99^{\circ} \mathrm{C}$. For p16 immunohistochemistry, any nuclear immunoreactivity of p16 was deemed positive. Only staining of the nucleus was considered as true immunoreactivity, but the presence of staining in the cytoplasm was recorded (Alexander et al., 2012).

\section{Statistical Analysis:}

An Excel spreadsheet was established for the entry of data. The analyses were carried with SPSS software (Statistical Package for the Social Sciences, version 24, SSPS Inc, Chicago, IL, USA). The normality of the data were assessed using Shapiro-Wilk Test. Numerical data were described as mean $\pm \mathrm{SD}$ if normally distributed; or median and interquartile range [IQR] if not normally distributed. Frequency tables with percentages were used for categorical variables. MannWhitney tests and Wilcoxon matched pairs test were used to compare nonparametric quantitative variables. Chisquare test or Fisher's exact tests were used to analyze categorical variables. A pvalue $<0.05$ war considered statistically significant.

\section{RESULTS}

There was a statistically significant difference between the studied groups regarding intensity of P16 staining. There was a statistically significant difference between the studied groups regarding percent of tumor stained (higher in those with cervical squamous cell carcinoma). On the other hand, there was a statistically non-significant difference between them regarding staining distribution and p16 expression (Table 1). 
Table (1): P16 expression in cervical and urinary bladder squamous cell carcinoma and comparison between the studied groups regarding immunohistochemical staining

\begin{tabular}{|l|c|c|c|}
\hline \multirow{2}{*}{ Parameter Diagnosis } & Cancer cervix & Cancer bladder & \multirow{2}{*}{ P } \\
\cline { 2 - 3 } & $\mathbf{N = 2 5 ( \% )}$ & $\mathbf{N = 2 5 ( \% )}$ & \multirow{2}{*}{0.008} \\
\hline $\begin{array}{l}\text { Expression: } \\
\text { Negative }\end{array}$ & $2(8)$ & $10(40)$ & \\
Positive & $23(92)$ & $15(60)$ & \multirow{2}{*}{$<0.001$} \\
\hline Intensity: & $0(0)$ & $2(13.3)$ & \\
Weak & $7(30.4)$ & $0(0)$ & \\
Moderate & $16(69.6)$ & $4(26.7)$ & \multirow{2}{*}{0.968} \\
Strong & $0(0)$ & $9(60)$ & \\
Focal & $\underline{N}=23(\%)$ & $\underline{N}=15(\%)$ & \multirow{2}{*}{0.005} \\
\hline Distribution: & $17(73.9)$ & $4(26.7)$ & \\
Nuclear & $6(26.7)$ & $38.33 \pm 29.5$ & \\
Nuclear and & & $30(10-90)$ & \\
cytoplasmic & $67.61 \pm 25.49$ & & \\
\hline Percentage: & $70(20-100)$ & & \\
Mean \pm SD & & & \\
Median (Range) & &
\end{tabular}

Among patients with cervical squamous cell carcinoma, there was a statistically non-significant relation between intensity of P16 staining and tumor staging. There was a statistically significant relation between intensity of P16 staining and tumor grading. On comparing each two groups of different intensity, the difference was a significant between negative and moderate staining. All patients with moderate staining had moderately differentiated tumor, while half of those with strong staining and all patients with negative staining had welldifferentiated tumor (Table 2).

Table (2): Relation intensity of immunohistochemical staining and histopathological characteristics of the studied patients with cancer cervix

\begin{tabular}{|c|c|c|c|c|c|}
\hline \multirow{2}{*}{ Parameters } & Negative & Moderate & Strong & \multirow[b]{2}{*}{$\mathbf{P}$} & \multirow[b]{2}{*}{$\begin{array}{l}\text { Pairwise } \\
\text { comparison }\end{array}$} \\
\hline & $\mathrm{N}=2(\%)$ & $\mathrm{N}=7(\%)$ & $\mathrm{N}=16(\%)$ & & \\
\hline $\begin{array}{l}\text { Staging: } \\
\text { 1B } \\
2 \mathrm{~A} \\
2 \mathrm{~B}\end{array}$ & $\begin{array}{c}0(0) \\
2(100) \\
0(0)\end{array}$ & $\begin{array}{c}5(71.4) \\
0(0) \\
2(28.6)\end{array}$ & $\begin{array}{c}6(37.5) \\
6(37.5) \\
4(25) \\
\end{array}$ & 0.089 & \\
\hline $\begin{array}{l}\text { Grading: } \\
\text { Poorly differentiated } \\
\text { Moderately differentiated } \\
\text { Well differentiated }\end{array}$ & $\begin{array}{c}0(0) \\
0(0) \\
2(100)\end{array}$ & $\begin{array}{c}0(0) \\
7(100) \\
0(0)\end{array}$ & $\begin{array}{c}2(12.5) \\
6(37.5) \\
8(50) \\
\end{array}$ & 0.001 & $\begin{array}{l}P_{1} 0.005 \\
P_{2} 0.181 \\
P_{3} 0.237 \\
\end{array}$ \\
\hline
\end{tabular}

P1 the difference between negative and moderate intensity P2 the difference between strong and moderate intensityP3 the difference between negative and strong intensity. 
Among patients with urinary bladder squamous cell carcinoma, there was a statistically non-significant relation between intensity of P16 staining and tumor grading. There was statistically significant relation between intensity of P16 staining and tumor grading. On comparing each two groups of different intensity, the difference was significant between negative and focal staining and also between weak and strong. Two thirds of those with focal staining and one half of those with strong staining had stage 2 B. Patients with weak staining had stage 1A (Table 3).

Table (3): Relation intensity of immunohistochemical staining and histopathological characteristics of the studied patients with cancer bladder

\begin{tabular}{|c|c|c|c|c|c|c|}
\hline \multirow{2}{*}{$\begin{array}{r}\text { Staining intensity } \\
\text { in cancer } \\
\text { bladder }\end{array}$} & Negative & Focal & Weak & Severe & \multirow[b]{2}{*}{$\mathbf{p}$} & \multirow[b]{2}{*}{$\begin{array}{l}\text { Pairwise } \\
\text { comparison }\end{array}$} \\
\hline & $\mathrm{N}=10(\%)$ & $\mathrm{N}=9(\%)$ & $\mathrm{N}=2(\%)$ & $\mathrm{N}=4(\%)$ & & \\
\hline $\begin{array}{l}\text { Staging: } \\
\text { 1A }\end{array}$ & $0(0)$ & $3(33.3)$ & $2(100)$ & $0(0)$ & \multirow{5}{*}{$<0.003$} & $\begin{array}{ll}\text { P1 } & 0.508 \\
\text { P2 } & 0.028\end{array}$ \\
\hline 1B & $2(20)$ & $0(0)$ & $0(0)$ & $0(0)$ & & P3 0.868 \\
\hline $2 \mathrm{~A}$ & $5(50)$ & $0(0)$ & $0(0)$ & $2(50)$ & & P4 0.102 \\
\hline $2 \mathrm{~B}$ & $0(0)$ & $6(66.7)$ & $0(0)$ & $2(50)$ & & P5 0.516 \\
\hline $3 \mathrm{~A}$ & $3(30)$ & $0(0)$ & $0(0)$ & $0(0)$ & & P6 0.035 \\
\hline \multirow{4}{*}{$\begin{array}{l}\text { Grading: } \\
\text { Poorly dif } \\
\text { Moderately } \\
\text { differentiat } \\
\text { Well diffe }\end{array}$} & & & & & \multirow{4}{*}{0.068} & \\
\hline & $3(30)$ & $0(0)$ & $0(0)$ & $2(50)$ & & \\
\hline & & & (1) & & & \\
\hline & $\begin{array}{l}5(50) \\
2(20)\end{array}$ & $\begin{array}{l}3(33.3) \\
6(66.7)\end{array}$ & $\begin{array}{c}2(100) \\
0(0)\end{array}$ & $\begin{array}{l}0(0) \\
2(50)\end{array}$ & & \\
\hline
\end{tabular}

$\chi 2$ Chi square test P1 the difference between negative and focal intensity P2 the difference between negative and weak intensity P3 the difference between negative and strong intensity P4 the difference between focal and weak intensity P5 the difference between strong and focal intensity P6 the difference between weak and strong intensity.

Moderate/strong staining intensity can predict staging $2 \mathrm{~B}$ among patients with cervical squamous cell carcinoma with sensitivity $100 \%$, specificity $89.5 \%$, positive predictive value $75 \%$, negative predictive value $100 \%$ and accuracy $92 \%$. Moderate/strong staining intensity can predict moderate/well-differentiated tumor among patients with cancer cervix with sensitivity $91.3 \%$, specificity $100 \%$, positive predictive value $100 \%$, negative predictive value $50 \%$ and accuracy $92 \%$ (Table 4).

Table (4): Validity of staining intensity in prediction of tumor stage and grade among patients with cancer cervix

\begin{tabular}{|l|c|c|c|c|c|}
\hline \multicolumn{1}{|c|}{ Cancer cervix } & Sensitivity & Specificity & PPV & NPV & Accuracy \\
\hline $\begin{array}{l}\text { Moderate/strong (stage, 2B, } \\
\text { 3A) }\end{array}$ & $100 \%$ & $89.5 \%$ & $75 \%$ & $100 \%$ & $92 \%$ \\
\hline $\begin{array}{l}\text { Moderate/strong for } \\
\text { moderate/well differentiated }\end{array}$ & $91.3 \%$ & $100 \%$ & $100 \%$ & $50 \%$ & $92 \%$ \\
\hline
\end{tabular}


Negative/weak staining intensity can predict staging $1 \mathrm{~A}, 1 \mathrm{~B}, 2 \mathrm{~A}$ with sensitivity $52.9 \%$, specificity $37.5 \%$, positive predictive value $64.3 \%$, negative predictive value $27.3 \%$ and accuracy $48 \%$ Focal/strong staining intensity can predict staging $2 \mathrm{~B}$ and $3 \mathrm{~A}$ among patients with cancer bladder with sensitivity $72.7 \%$, specificity $35.7 \%$, positive predictive value $47.1 \%$, negative predictive value $62.5 \%$ and accuracy $52 \%$. Negative/weak staining intensity can predict moderate/well-differentiated tumor among patients with cancer cervix with sensitivity $81.8 \%$, specificity $21.4 \%$, positive predictive value $45 \%$, negative predictive value $60 \%$ and accuracy $48 \%$ (Table 5).

Table (5): Validity of staining distribution in prediction of tumor stage and grade among patients with cancer bladder

\begin{tabular}{|l|c|c|c|c|c|}
\hline Cancer bladder & Sensitivity & Specificity & PPV & NPV & Accuracy \\
\hline $\begin{array}{l}\text { Negative and weak*stage } \\
(\mathbf{1 A}, \mathbf{1 B}, \mathbf{2 A})\end{array}$ & $52.9 \%$ & $37.5 \%$ & $64.3 \%$ & $27.3 \%$ & $48 \%$ \\
\hline $\begin{array}{l}\text { Focal/strong } \\
\text { (stage, 2B, 3A) }\end{array}$ & $72.7 \%$ & $35.7 \%$ & $47.1 \%$ & $62.5 \%$ & $52 \%$ \\
\hline $\begin{array}{l}\text { Negative/weak for } \\
\text { moderate/well differentiated }\end{array}$ & $81.8 \%$ & $21.4 \%$ & $45 \%$ & $60 \%$ & $48 \%$ \\
\hline
\end{tabular}

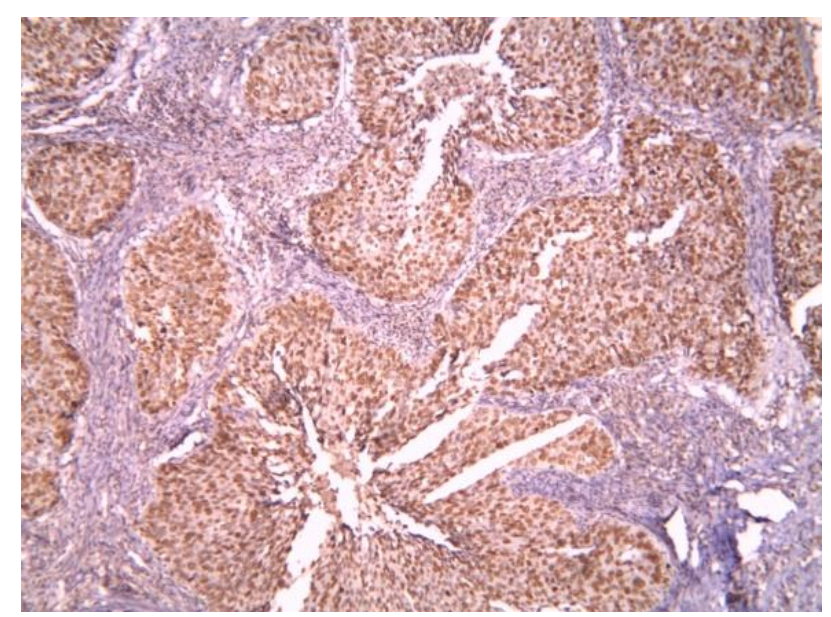

Figure (1): Cervical squamous cell carcinoma; strong positive for P16, nuclear and cytoplasmic distribution 


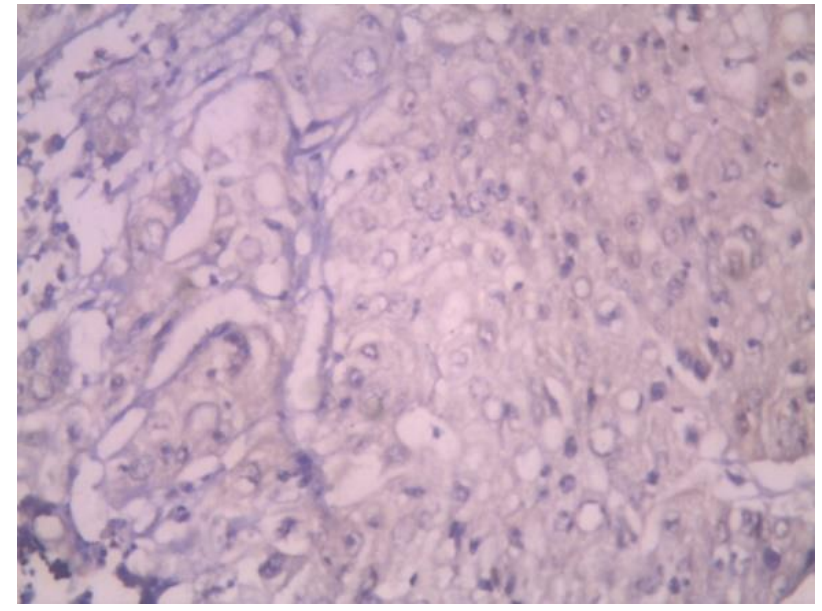

Figure (2): Cervical squamous cell carcinoma; negative for P16

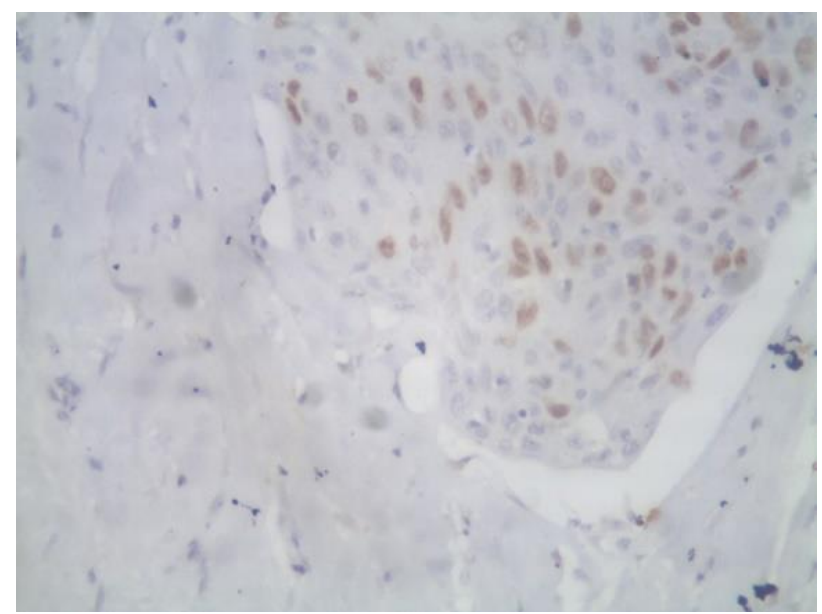

Figure (3): Urinary bladder squamous cell carcinoma; weak positive for P16.

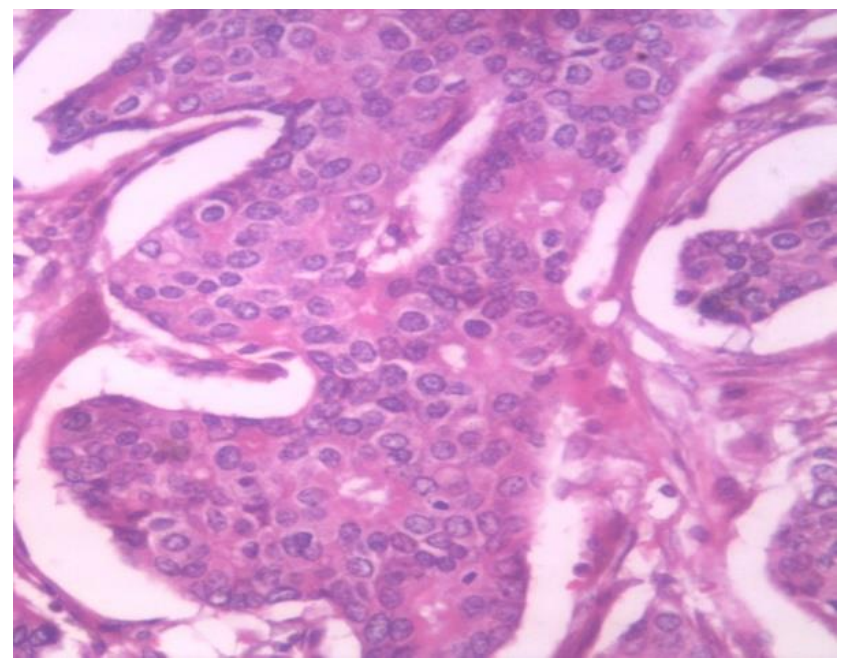

Figure (4): H \& E staining of moderately differentiated urinary bladder squamous cell carcinoma 


\section{DISCUSSION}

p16 INK4a (p16) is a tumor suppressor gene that binds to and inhibits cyclindependent kinase CDK4 complex. When an allele mutation or inactivation by hypermethylation of p16 INK4a occurs, this protein loses the capacity to block cyclin D-CDK4 activity. Under these conditions, the phosphorylation of $\mathrm{Rb}$ can occur, and the progression of the cell cycle is therefore uninhibited (Redman et al., 2012).

Cancer cervix is the second most frequent type of cancer in women in underdeveloped regions; it is the third most frequent cancer in the female population and a public health problem mostly affecting poor women without access to public health services. In almost all cases of cervical cancer, human papillomavirus (HPV) infection is a critical risk factor (Nicol et al., 2016).

Worldwide, one of the most frequent HPV-related gynecologic neoplasias is squamous cell carcinomas (SCC) of the uterine cervix, which is known to express p16 by immunohistochemistry (CioffiLavina et al., 2010). SCC of the urinary bladder represents approximately $5 \%$ of all malignant bladder tumors in the United States (Lagwinski et al., 2010).

In the present study, P16 was positively expressed in 23 cases (92\%) and 15 cases $(60 \%)$ of cervical and urinary bladder squamous cell Carcinoma respectively. Negative expression was observed in 2 cases (8\%) and 10 cases $(40 \%)$ of cervical and urinary bladder squamous cell carcinoma respectively.

Near to our study, Gupta et al. (2010) was conducted on cases of squamous cell carcinoma of the cervix with $95.2 \%$ of cases are P16 positive and only $4.8 \%$ are negative with $\mathrm{p} 16$.

Cioffi-Lavina et al. (2010), P16 was positively expressed in $86 \%$ of cases $37 \%$ of cervical and urinary bladder squamous cell carcinoma respectively. Negative expression was observed in $14 \%$ and $63 \%$ of cervical and urinary bladder squamous cell carcinoma respectively. the difference between that study and our study may return to the variation in the number of cases or to different methods of scoring of p16 and also to grading and staging of tumors.

P16 expression in squamous cell carcinoma of the urinary bladder in our study was more than that of Alexander et al. (2012) who found that $31 \%$ were positive and $69 \%$ were negative. That difference in the results of both studies may return to different monoclonal antibodies used in them, as we use P16NK4A, but Alexander et al. (2012) used P16E6H4.

Similar to our study, Kanthiya et al. (2016) found that p16 expression in $91 \%$ of cases of squamous cell carcinoma of the cervix. The similarity in the expression in that and our study may be due to nearly equal number of studied cases. Other previous studies reported p16 in $80 \%$ to $100 \%$ in cancer cervix (Benevolo et al., 2010, Hariri \& Øster, 2011 and Sari Aslani et al., 2013). The variation of expression rates may partly depend on the criteria defining positive expression.

Distribution of P16 in squamous cell carcinoma of urinary bladder in our study was nuclear in $73.3 \%$ and both nuclear and cytoplasmic in $26.7 \%$. 
Alexander et al. (2012) found that nuclear and cytoplasmic distribution of P16 in urinary bladder squamous cell carcinoma was more than our study. It was $84.6 \%$, but nuclear distribution was less than our study. It was $15.4 \%$. This difference may return to different monoclonal antibodies of P16 used in both studies.

In our study, among patients with cancer cervix, there was a statistically non-significant relation between intensity of P16 staining and tumor staging, but there was a statistically significant relation between intensity of P16 staining and tumor grading. On comparing each two groups of different intensity, the difference was a significant between negative and moderate staining. All patients with moderate staining had moderately differentiated tumor, while half of those with strong staining and all patients with negative staining had welldifferentiated tumor.

Like to our study, Gupta et al. (2010) stated that there was a progressive increase in the percentage of positivity as well as intensity of staining through increasing grades of cervical squamous cell carcinoma.

\section{CONCLUSION}

The relationship between p16INK4A and HPV E7 inactivated RB protein, immunohistochemical detection by expression of p16INK4a can be used as a specific diagnostic marker for all degrees of cervical squamous cell carcinoma, and probably as a surrogate marker for HPV infection. However, p16 immunohistochemical expression alone should not be used for differentiation between cervical and urinary squamous cell carcinoma.

Acknowledgement: Not applicable

Conflicts of Interest: The authors declare that they do not have any conflict of interest.

Funding: None.

\section{REFERENCES}

1. Alexander RE, Hu Y, Kum JB, Montironi R, Lopez-Beltran A and Maclennan GT. (2012): p16 expression is not associated with human papillomavirus in urinary bladder squamous cell carcinoma. Modern Pathology, 25(11): 1526-1533.

2. Benevolo M, Mottolese M, Marandino F, Vocaturo G, Sindico R, Piperno G, Mariani L, Sperduti I, Canalini P, Donnorso RP and Vocaturo A. (2010): Immunohistochemical expression of p16(INK4a) is predictive of HRHPV infection in cervical low-grade lesions. Modern Pathology, 19(3): 384-391.

3. Cioffi-Lavina M, Chapman-Fredricks J, Gomez-Fernandez C, Ganjei-Azar P, Manoharan M and Jorda M. (2010): P16 expression in squamous cell carcinomas of cervix and bladder. Applied Immunohistochemistry \& Molecular Morphology, 18(4): 344-347.

4. Fedewa SA, Soliman AS, Ismail K, Hablas $A$ and Seifeldin IA. (2013): Incidence analyses of bladder cancer in the Nile delta region of Egypt. Cancer epidemiology, 33(34): $176-181$.

5. Ferlay J, Shin HR, Bray F, Forman D and Parkin DM. (2013): Cancer incidence and mortality worldwide: IARC CancerBase No. International Agency for Research on Cancer, 2: $10-11$.

6. Gupta R, Srinivasan R, Nijhawan R, Suri V and Uppal R. (2010): Protein p 16INK4A expression in cervical intraepithelial neoplasia and invasive squamous cell carcinoma of uterine cervix. Indian J Pathol Microbiol., $53: 7-11$ 
7. Hariri J and Øster A. (2011): The negative predictive value of p16INK4a to assess the outcome of cervical intraepithelial neoplasia 1 in the uterine cervix. International Journal of Gynecological Pathology, 26(3): 223-228.

8. Kanthiya K, Khunnarong J, Tangjitgamol S, Puripat $N$ and Tanvanich S. (2016): Expression of the p16 and Ki67 in Cervical Squamous Intraepithelial Lesions and Cancer. Asian Pacific Journal of Cancer Prevention, 17: 3201-3206.

9. Lagwinski N, Thomas A, Stephenson AJ, Campbell S, Hoschar AP, El-Gabry E, Dreicer $R$ and Hansel DE. (2010): Squamous cell carcinoma of the bladder: a clinicopathologic analysis of 45 cases. The American Journal of Surgical Pathology, 31(12): 1777-1787.

10. Netto GJ and Epstein JI. (2011): Immunohistology of the Prostate, Bladder, Kidney, and Testis. In: D. J. Dabbs (ed). Diagnostic Immunohistochemistry. 3rd ed. Pbl. Philadelphia: W.B. Saunders, Pp. 593661.

11. Nicol AF, Andrade CV, Russomano FB, Rodrigues LL, Oliveira NS and Provance DW (2016): HPV vaccines: a controversial issue? Braz J Med Biol Res., 49(5):5060-66.

12. Rabban JT, Soslow RA and Zaloudek CZ. (2010): Immunohistology of the Female Genital Tract. In: D. J. Dabbs (ed). Diagnostic
Immunohistochemistry. 3rd ed. Pbl. Philadelphia: W.B. Saunders, Pp. 690-762.

13. Redman R, Rufforny I, Liu C, Wilkinson EJ and Massoll NA. (2012): The utility of p16(Ink4a) in discriminating between cervical intraepithelial neoplasia 1 and nonneoplastic equivocal lesions of the cervix. Archives of Pathology \& Laboratory Medicine, 132(5): 795-799.

14. Sari Aslani F, Safaei A, Pourjabali $M$ and Momtahan M. (2013): Evaluation of Ki67, p16 and CK17 Markers in Differentiating Cervical Intraepithelial Neoplasia and Benign Lesions. Iranian Journal of Medical Sciences, 38(1): 15-21.

15. Shafti V and Ghalandari M. (2018): Knowledge about pap smear test, cervical cancer and human papilloma virus among women referred to gynecology clinic of tonekabon shahid rajaei hospital in 2016. Medical Sciences Journal of Islamic Azad University, 27(4): 294-300.

16. Zheng YL, Amr S, Saleh DA, Dash C, Ezzat S, Mikhail NN, Gouda I, Loay I, Hifnawy T and Loffredo CA. (2012): Urinary bladder cancer risk factors in Egypt: a multicenter case-control study. Cancer epidemiology, biomarkers \& prevention : a publication of the American Association for Cancer Research, cosponsored by the American Society of Preventive Oncology, 21(3): 537-546. 


\section{دراسة هيستوكيميائية مناعية لتعبير بى 16 فى سرطان الخلايا الحرشفية فى عثق الرحم والمثانة البوليه مئيه}

إسماعيل البيومي، عماد الدين مطر، ياسر الدويك، أحمد قنديل

قسم علم الأمراض، كلية الطب، جامعة الأزهر

بريد إلكتروني: talaatismail72@gmail.com

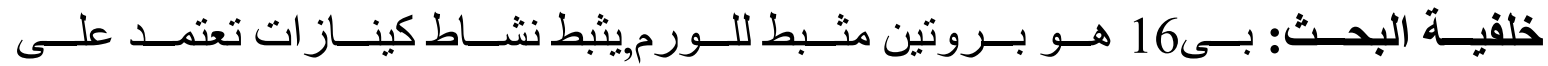

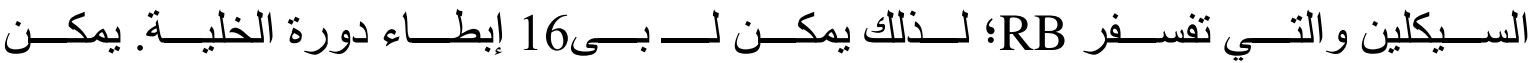

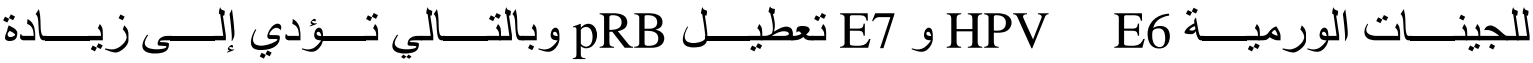

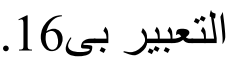

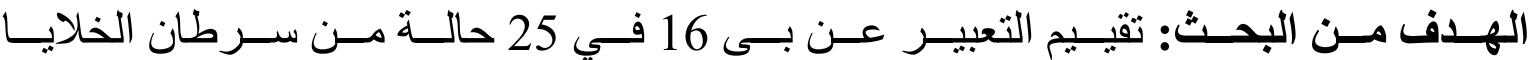
الحرشفية العنقية و 25 حالة من سرطان الخلايا الحرشفية في المثانة البولية.

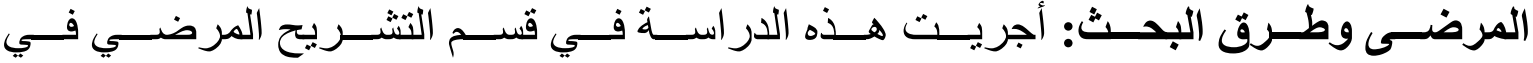

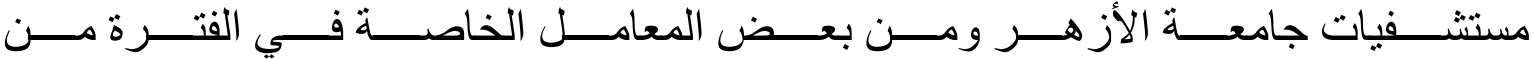

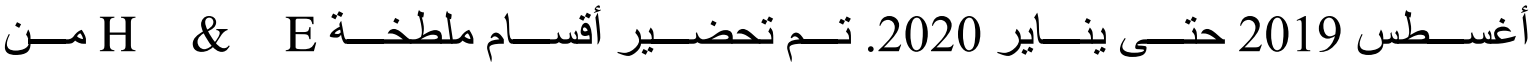

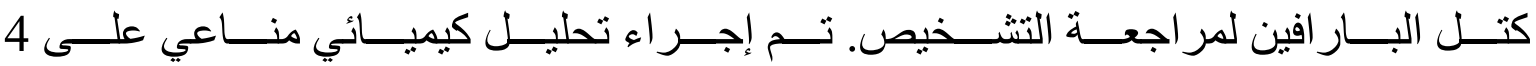

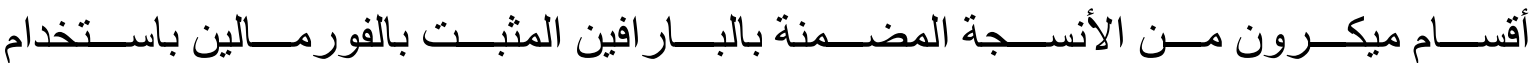

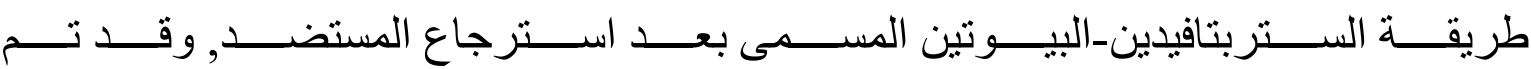

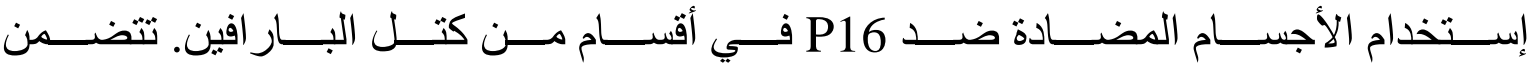

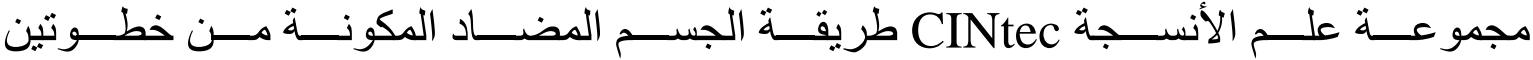
للكثف عن الجسم المضاد p16 البشري.

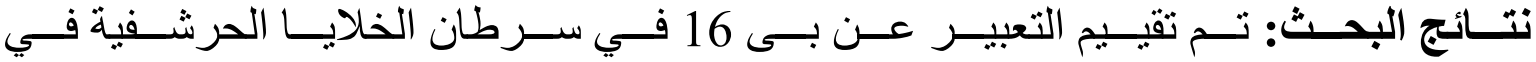

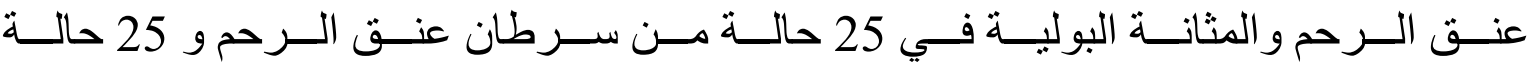

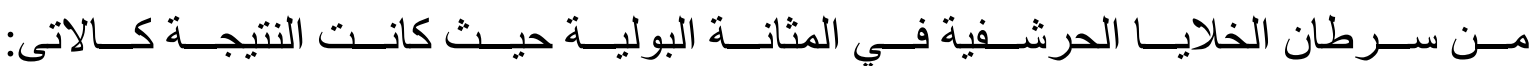

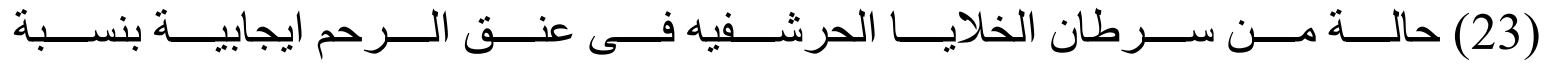




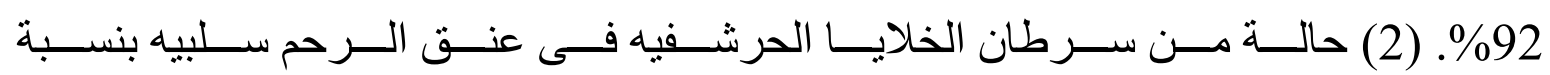

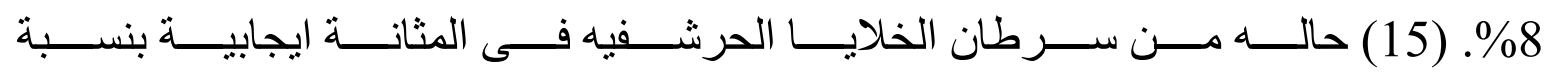

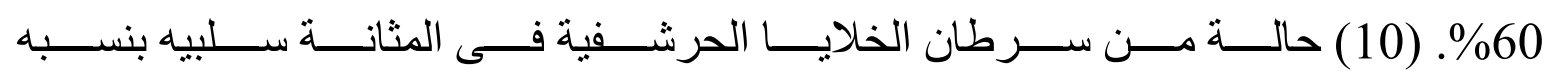

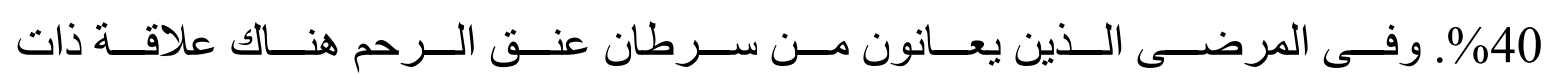

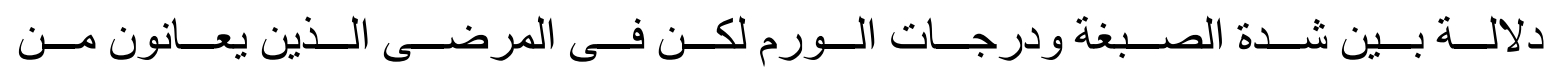

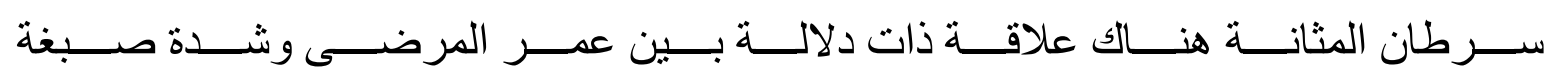
بی16.

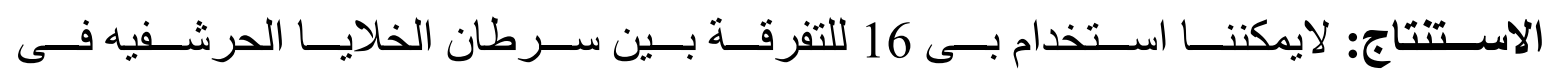

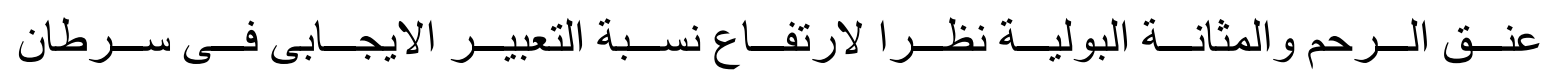
الخلايا الحرشفية فى المثانة البولية. الكلمات الدالة: سرطان عنق الرحم، سرطان المثانة، بى 16. 